This is the author's final, peer-reviewed manuscript as accepted for publication. The publisher-formatted version may be available through the publisher's web site or your institution's library.

\title{
Molecular markers for leaf rust resistance gene Lr42 in wheat
}

Zhengli Liu, Robert L. Bowden and Guihua Bai

\section{How to cite this manuscript}

If you make reference to this version of the manuscript, use the following information:

Liu, Z., Bowden, R. L., \& Bai, G. (2013). Molecular markers for leaf rust resistance gene Lr42 in wheat. Retrieved from http://krex.ksu.edu

\section{Published Version Information}

Citation: Liu, Z., Bowden, R. L., \& Bai, G. (2013). Molecular markers for leaf rust resistance gene Lr42 in wheat. Crop Science, 53(4), 1566-1570.

Copyright: ( ) Crop Science Society of America

Digital Object Identifier (DOI): doi:10.2135/cropsci2012.09.0532

Publisher's Link: https://www.crops.org/publications/cs/articles/53/4/1566

This item was retrieved from the K-State Research Exchange (K-REx), the institutional repository of Kansas State University. K-REx is available at http://krex.ksu.edu 
Molecular Markers for Leaf Rust Resistance Gene Lr42 in Wheat

Zhengli Liu, Robert L. Bowden and Guihua Bai ${ }^{\square}$,

Z. Liu, Institute of Millet Crops, Hebei Academy of Agricultural \& Forestry Sciences,

Shijiazhuang, Hebei, 050031 China; Z. Liu and G. Bai, Dep. of Agronomy, Kansas State

University; R. L. Bowden and G. Bai, USDA-ARS, Hard Winter Wheat Genetics

Research Unit, Manhattan, KS 66506

Received -----.. *Corresponding author (guihua.bai@ars.usda.gov).

Abbreviations: Infection type, IT; short arm of chromosome 1D, 1DS; simple sequence repeats, SSR; quantitative trait locus, QTL; marker-assisted selection, MAS. 
Abstract

Wheat leaf rust, caused by Puccinia triticina Eriks., is an important wheat foliar disease worldwide. Growing cultivars incorporating genetic resistance is one of the most effective approaches for disease control. Leaf rust resistance gene Lr42 was identified from a wheat relative, Aegilops tauschii Coss, and has been transferred into hard winter wheat. A previous study identified two markers closely linked to the gene on the short arm of chromosome 1D (1DS) using a near isogenic population, but flanking markers for $L r 42$ were not found. In this study, a new mapping population was developed from a cross between 'KS93U50' (a Lr42 carrier) and a susceptible parent, 'Morocco'. An F 2 population was analyzed with all simple sequence repeat (SSR) markers available from chromosome $1 \mathrm{D}$ and $\mathrm{F}_{2}$ plants and $\mathrm{F}_{3}$ families were evaluated for seedling resistance to isolate PNMR, a rust isolate avirulent to $L r 42$. The $\mathrm{F}_{2}$ and $\mathrm{F}_{3}$ rust data showed that $L r 42$ was recessive. Seven markers formed the linkage group on 1DS. The Lr42 region was flanked by two simple sequence repeat (SSR) markers; Xwmc432 and Xgdm33 at $17 \mathrm{cM}$ apart. The results confirmed that $L r 42$ is positioned on the distal end of chromosome 1DS. The flanking markers for Lr42 should be useful for map-based cloning and marker-assisted pyramiding of Lr42 with other leaf rust resistance genes. 


\section{Introduction}

Leaf rust of wheat (Triticum aestivum L.), caused by Puccinia triticina Eriks., is one of the most important wheat foliar diseases worldwide (Kolmer, 1996). Severe leaf rust epidemics can cause yield losses up to $40 \%$ (Knott, 1989). Growing genetically resistant cultivars is one of the most effective strategies to minimize yield losses due to the disease. To date, at least 71 genes for resistance to leaf rust have been catalogued in wheat (Singh et al., 2012). Of these, about half were introgressed from related species. Many of them were from Ae. tauschii Coss, the D genome donor of common wheat, including Lr21 (1DS), Lr22a (2DS), Lr32 (3DS), Lr39 (2DS), and Lr42 (1DS) (Rowland and Kerber, 1974, Kerber, 1987, Gill et al., 1991, Cox et al., 1994).

Most $L r$ genes confer race-specific seedling resistance and are vulnerable to defeat by new virulent races. Greater durability of resistance could be achieved through combinations of race-specific genes or by using race-nonspecific resistance genes, such as Lr34 and Lr46 (Kolmer et al, 2008a \& b). However, such genes provide low levels of resistance when deployed alone or singly (Zhang et al., 2008). A third option is to combine both race-specific and race-nonspecific resistance.

Combining race-specific and race-nonspecific resistance genes in a single cultivar could significantly improve both durability and the level of resistance (Kolmer et al., 2008a, Zhang et al., 2008). For instance, in spring wheat, the combination of Lr16, Lr23 (race-specific resistance genes) and Lr34 (a race-nonspecific resistance gene) has provided effective and durable resistance for many years (Kolmer et al., 2008a \& b). Genes Lr34 and Lr13 were demonstrated to enhance the level of resistance synergistically when in combination with other leaf rust resistance genes (Germán and 
Kolmer, 1992; Kolmer, 1992). Two recent papers also demonstrated the ability of quantitative race-nonspecific resistance to extend the usefulness of qualitative race-specific resistance genes (Brun et al, 2010; Pailloix et al, 2009).

Stacking of several leaf rust resistance genes using phenotypic selection is difficult. A variety of rust races are often not available that could distinguish the presence or absence of different genes. If some genes in the stack confer high resistance, they can mask the phenotypic expression of other genes. Molecular markers can make it possible to stack several genes simultaneously in a single genetic background, therefore, identifying closely linked markers for each resistance gene is essential for successful use of these genes in breeding.

Lr42 is a gene conferring rust resistance at both seedling and adult plant stages and remains effective against all leaf rust races reported to date (Sun et al., 2010). Lines containing Lr42 have been used as a parent in some breeding programs with success (Bacon et al., 2006; Singh et al., 2007). Previous work located Lr42 on 1DS (Cox et al., 1994) and found that Lr42 also played a significant role in increasing wheat yield and kernel size, apparently due to the resistance (Martin et al., 2003). Using molecular mapping, Czembor et al, (2008) located Lr42 to a different chromosome (3D) using DArT markers and reported that the gene was dominant. Sun et al. (2010) further mapped Lr42 to the distal end of 1DS using SSR markers and the same near-isogenic population developed by Martin et al. (2003), and identified two closely linked markers. Thus additional mapping work using different populations is necessary to validate the chromosome location of Lr42. The current study examined a population derived from the cross 'KS93U50' $\mathrm{x}$ 'Morocco' to: 1) confirm the gene location in a new population, 2) 
study the inheritance pattern of the gene, 3) identify flanking markers linked to the gene for marker-assisted selection (MAS).

\section{Materials and Methods}

\section{Plant materials and rust inoculation}

The mapping population was developed by crossing 'KS93U50' and 'Morocco'. 'KS93U50' is a hard red winter wheat accession containing Lr42 selected from 'KS91WGRC11' (PI 566668, pedigree 'Century'*3/T. tauschii TA2450) and provided by the Wheat Genetic and Genomic Resources Center, Kansas State University, Manhattan KS. Morocco is an old soft white spring cultivar originally collected from North Africa and frequently used as a susceptible check for leaf, stem, and stripe rust. A total of $371 \mathrm{~F}_{2}$ plants derived from the cross 'KS93U50' $\mathrm{x}$ 'Morocco' was inoculated with rust race PNMR. PNMR is avirulent to 'KS93U50', but virulent to several susceptible cultivars tested (Sun et al., 2010). All $\mathrm{F}_{2}$ plants and both parents were planted in 72-cell plastic flats and inoculated with PNMR at the two-leaf stage. Before inoculation, rust spores from a liquid $\mathrm{N}_{2}$ tank were heat shocked in water bath at $40^{\circ} \mathrm{C}$ for $5 \mathrm{~min}$ to break dormancy. The spores were suspended in Soltrol 170 light oil (Chevron Phillips Chemical Company, Woodlands, TX) and misted uniformly over the seedling leaves using a pressure sprayer. After inoculation, the plants were incubated in a moist chamber at $20{ }^{\circ} \mathrm{C}$ for $24 \mathrm{~h}$ before being moved to a greenhouse bench for rust establishment. The plants were grown at $20{ }^{\circ} \mathrm{C}$ supplemented with $10 \mathrm{~h}$ daylight. The rust infection type (IT) on a 1 to 4 scale as described previously (Stakman et al., 1962; Roelfs and Martens, 1988), was recorded at $10 \mathrm{~d}$ after inoculation and rechecked $2 \mathrm{~d}$ 
later for confirmation. After rust data were collected, all $\mathrm{F}_{2}$ plants were transplanted to $13 \mathrm{~cm}$ by $13 \mathrm{~cm}$ plastic pots for seed increase. Seeds from $361 \mathrm{~F}_{2}$ plants $\left(10 \mathrm{~F}_{2}\right.$ plants did not set any seed) were harvested individually and planted in 72-cell plastic growth trays for rust evaluation. Six seeds per $\mathrm{F}_{2: 3}$ family were planted and the experiments had two replications. Six seeds per parent also were planted in each tray as control. Rust inoculation and disease scoring for the parents and $\mathrm{F}_{2: 3}$ families were the same as for the $F_{2}$ population. Based on parent reactions to $P N M R$, plants with $I T \leq 2$ were classified as resistant and $\mathrm{IT} \geq 2^{+}$as susceptible for segregation analysis. The segregation ratio from $\mathrm{F}_{2: 3}$ families was used to determine the genotypes of $\mathrm{F}_{2}$ plants and the combined data from both generations were used to determine inheritance pattern.

\section{Marker genotyping and data analysis}

After rust evaluation, newly developed disease-free wheat leaf tissue was collected in 1.1 mL 96-deepwell plates for DNA isolation. Tissue samples were immediately dried in a freeze-dryer (ThermoSavant, Holbrook, NY) for $48 \mathrm{~h}$ and ground to fine powder using a Mixer Mill (MM300, Rotsch, Germany) by shaking the tubes at 25 times per s for 5 min with a 3.2-mm stainless steel bead in each well. Genomic DNA was extracted using a modified cetyltrimethyl ammonium bromide method (Sun et al., 2009). Because Lr42 was previously located on chromosome 1D (Cox et al., 1994), 27 SSR primers on chromosome 1D (Somers et al., 2004; Song et al., 2005, Roder et al., 1998) were selected to screen the parents for polymorphism. PCR amplifications were performed in a Tetrad Peltier DNA Engine (Bio-Rad Lab, Hercules, CA). A $12 \mu \mathrm{L}$ PCR mixture containing 1.2 $\mu \mathrm{L}$ of 10X PCR buffer (Bioline, Taunton, MA), $2.5 \mathrm{mM}$ of $\mathrm{MgCl}_{2}, 200$ 
$\mu \mathrm{M}$ of each dNTP, $50 \mathrm{nM}$ of forward M13-tailed primer, $250 \mathrm{nM}$ of reverse primer and $200 \mathrm{nM}$ of M13 fluorescent-dye-labeled primer, 0.6 U of Taq DNA polymerase, and about 50 ng template DNA. A touchdown PCR program was used for PCR amplification. In brief, the reaction was incubated at $95{ }^{\circ} \mathrm{C}$ for 5 min then continued for 5 cycles of 1 min at $96{ }^{\circ} \mathrm{C}, 5$ min at $68{ }^{\circ} \mathrm{C}$ with a decrease of $2{ }^{\circ} \mathrm{C}$ in each subsequent cycle, and 1 min at $72{ }^{\circ} \mathrm{C}$. For another 5 cycles, the annealing temperature started at $58{ }^{\circ} \mathrm{C}$ for 2 min with a decrease of $2{ }^{\circ} \mathrm{C}$ for each subsequent cycle. Reactions then went through an additional 25 cycles of $1 \mathrm{~min}$ at $96{ }^{\circ} \mathrm{C}, 1 \mathrm{~min}$ at $50{ }^{\circ} \mathrm{C}$, and $1 \mathrm{~min}$ at $72{ }^{\circ} \mathrm{C}$ with a final extension at $72{ }^{\circ} \mathrm{C}$ for 5 min. PCR products were analyzed on an ABI PRISM 3730xl DNA Analyzer (Applied Biosystems, Foster City, CA). Data were analyzed using GeneMarker software ver. 1.6 (SoftGenetics LLC. State College PA), and manually checked twice to remove ambiguous data.

A linkage map was constructed using Kosambi (1944) function and MultiPoint package (available at http://www.MultiQTL.com). A logarithm of odds (LOD) threshold of 3 was used to identify linkage groups.

\section{Results}

Ten days after inoculation with PNMR, the susceptible parent 'Morocco' showed severe rust symptoms with IT $\geqslant 2^{+}$, while most of plants of the resistant parent, 'KS93U50', only showed tiny pustules surrounded by necrosis and with IT $\leqslant 2$. In $F_{2}$ and $F_{3}$ populations, IT ranged from 1 to 4 for different genotypes. Because most of the plants of the susceptible parent had IT $\geqslant 3$ with only a few plants that had IT $=2^{+}$, plants with IT $\geqslant 2^{+}$were classified as susceptible genotypes and plants with IT $\leqslant 2$ 
were classified as resistant genotypes. Of $371 \mathrm{~F}_{2}$ plants evaluated 282 were susceptible and 89 were resistant, fitting a $3: 1$ ratio $\left(x^{2}=0.202, P=0.653\right)$, indicating that $L r 42$ behaved as recessive in the 'KS93U50' $x$ 'Morocco' population. The $\mathrm{F}_{2: 3}$ family segregation fit a 1 resistant: 2 segregating: 1 susceptible ratio $\left(x^{2}=7.693, p=0.0214\right)$, with slight distortion toward susceptible families (Table 1). In each segregating family, most of the plants were susceptible, which confirmed that $L r 42$ is recessive.

Of the 27 SSR markers available on chromosome 1D, 11 proved polymorphic between two parents. Eight markers were mapped to one linkage group and three others were unlinked. Two of the eight markers, Xbarc229 and Xwmc336, showed significant segregation distortion and were removed from the linkage group. The map with six markers covered $68.5 \mathrm{cM}$ on chromosome 1D (Fig. 1). Lr42 was mapped between Xwmc432 and Xgdm33 at $4 \mathrm{cM}$ from Xwmc432. A slight segregation distortion was observed for the markers in the region of Lr42 (Table 2).

Of the primers for these markers, Gdm33 amplified a fragment of $177 \mathrm{bp}$ in 'KS93U50' and a fragment of 145 bp in 'Morocco'. Primer Wmc432 amplified two fragments in each of the two parents, 204 and 212 bp from 'KS93U50', and 203 and 218 from 'Morocco', but only the larger fragments were segregating in the population and mapped in the Lr42 region.

\section{Discussion}

In this study, most $F_{2}$ plants were susceptible and segregation indicated a single recessive gene for resistance. Segregation in the $F_{3}$ population was consistent with the premise that resistance to rust isolate PNMR due to Lr42 in KS93U50 was recessive. 
This result disagrees with previous reports that Lr42 was dominant (Czembor et al., 2008) or partially dominant (Cox et al., 1994). The discrepancy could result from different isolates and genetic materials used in different studies. Kolmer and Dyck (1994) demonstrated that expression of resistance genes could range from complete dominance to complete recessiveness and the expression of resistance and avirulence genes in wheat leaf rust system is highly dependent on the genotypes of the host lines and pathogen isolates used. In this study, 'KS93U50' was used as the source of Lr42 that was a selection from 'KS91WGRC11', while 'KS91WGRC11' was used in the other studies (Czembor et al. 2008, Cox et al. 1994). Pathogen inocula used in these studies might also be different. In this study, several local isolates were evaluated using a set of parents and near-isogenic lines and we found that PNMR could clearly differentiate Lr42 from various susceptible genotypes (Sun et al., 2010). Thus it was the isolate of choice used in this study. However, for direct resistance evaluation in segregating breeding materials, this isolate may not be ideal because phenotypic differences are not sufficient to distinguish heterozygous from homozygous susceptible plants.

The closest marker to Lr42 is Xwmc432, which confirmed the previous report (Sun et al., 2010). In the previous study, a backcross derived homozygous near-isogenic population was used and disease scores were treated as binary data. In this study, $\mathrm{F}_{2}$ was used for mapping. The genetic distance between Lr42 and Xwmc432 is about $4 \mathrm{cM}$ longer in this study than in the previous study. In this study, $F_{3}$ rust data agreed with $F_{2}$ in general, but heterozygous status of some $F_{2}$ plants could not be detected due to limited number of $\mathrm{F}_{3}$ plants per family were evaluated for rust resistance, which might contribute to expended genetic distance between $\mathrm{Lr} 42$ and Xwmc432. In addition, we 
identified one new marker, Xgdm33, distal to Lr42. Xwmc432 and Xgdm33 defined Lr42 in a $17.8 \mathrm{cM}$ region. Thus they can be used as flanking markers for further fine mapping in the region to facilitate map-based cloning of the gene.

Two markers developed in this study are good candidate markers for MAS of Lr42. Primer Wmc432 amplified two fragments in both parents, but only the $212 \mathrm{bp}$ fragment from 'KS93U50' and the $218 \mathrm{bp}$ fragment from 'Morocco' associated with Lr42, as in a previous study (Sun et al., 2010). This marker should be the first choice for MAS.

Because allele size differences between the two parents were relatively large for Xwmc432 and Xgwm33, they can be analyzed in an agarose gel in breeding programs. A high concentration agarose gel is recommended when using Xwmc432.

In this study, four markers closely linked to Lr42 were positioned on chromosome 1DS based on the previously reported linkage maps (Somers et al., 2004, Song et al., 2005), which disagrees with Czembor et al. (2008). However, our results are in agreement with the previous report by Sun et al. (2010) despite different types of populations (near-isogenic verse $\mathrm{F}_{2}$ populations) and susceptible parents used in the two studies. The discrepancy among different studies could be due to difference in resistant parents used in different studies as discussed previously. Thus, if the markers developed in this study are to be used for screening Lr42 gene, it is advised that 'KS93U50' be used as the source of resistance.

\section{Acknowledgements}

This project was partially supported by the National Research Initiative Competitive Grants CAP project 2011-68002-30029 from the USDA National Institute of Food and 
Agriculture and USDA-ARS project 5430-21000-006-00D. The authors would like to thank Dr. Paul St. Amand, USDA Central Small Grain Genotyping Center, and Dr. Chengsong Zhu, Department of Agronomy, Kansas State University, Manhattan KS, for technical assistance. Mention of trade names or commercial products in this article is solely for the purpose of providing specific information and does not imply recommendation or endorsement by the U.S. Department of Agriculture. USDA is an equal opportunity provider and employer. This is contribution No. 12-414-J from the Kansas Agricultural Experiment Station, Manhattan, KS.

\section{References}

Bacon, R.K., J.T. Kelly, E.A. Milus, and C.E. Parsons. 2006. Registration of soft wheat germplasm AR93005 resistant to leaf rust. Crop Sci. 46:1398-1399.

Brun, H., A. Chèvre, B.D. Fitt, S. Powers, A. Besnard, M. Ermel, V. Huteau, B. Marquer, F. Eber, M. Renard, and D. Andrivon. 2010. Quantitative resistance increases the durability of qualitative resistance to Leptosphaeria maculans in Brassica napus. New Phytologist 185:285-299.

Churchill, G.A., and R.W. Doerge. 1994. Empirical threshold values for quantitative trait mapping. Genetics 138:963-971.

Cox, T.S., W.J. Raupp, and B.S. Gill. 1994. Leaf rust-resistance genes Lr41, Lr42, and Lr43 transferred from Triticum tauschii to common wheat. Crop Sci. 34:339-343.

Czembor, P.C., M. Radecka-Janusik, A. Pietrusińska, and H.J. Czembor. 2008.

Proceeding of the $11^{\text {th }}$ International Wheat Genetics Symposium Aug 24-29, 2008, Brisbane, QLD, Australia, Ed. R. Appel, R. Eastwood, E. Lagudar, P. Langridge, M. 
Mackay, L. McIntyre, P. Sharp. 739-740 (824pp).

Germán S.E., and J.A. Kolmer. 1992. Effect of the gene Lr34 in the enhancement of resistance to leaf rust of wheat. Theor. Appl. Genet. 84:97-105.

Gill, B.S., W.J. Raupp, L.E. Browder, T.S. Cox, and R.G. Sears. 1991. Registration of KS89WGRC7 leaf rust resistant hard red winter wheat germplasm. Crop Sci. 31:246.

Kerber, E.R. 1987. Resistance to leaf rust in hexaploid wheat: Lr32 a third gene derived from Triticum tauschii. Crop Sci. 27:204-206.

Knott, D.R. 1989. The wheat rusts-breeding for resistance. Monographs on theoretical and applied genetics, vol. 12. Springer, Berlin Heidelberg New York.

Kolmer, J.A. 1992. Enhanced leaf rust resistance in wheat conditioned by resistance gene pairs with Lr13. Euphytica 61:123-130.

Kolmer, J.A. 1996. Genetics of resistance to wheat leaf rust. Ann. Rev. Phytopath. $34: 435-455$.

Kolmer, J.A., D.L. Long, and M.E. Hughes. 2008b. Physiological specialization of Puccinia triticina on wheat in the United States in 2006. Plant Dis. 92:1241-1246.

Kolmer, J.A., and P.L. Dyck. 1994. Gene expression in the Triticum aestivum-Puccinia recondite f. sp. tritici gene-for-gene system. Phytopathology 84:437-440.

Kolmer, J.A., X. Chen, Y. Jin. 2008a. Diseases which challenge global wheat production the wheat rusts. In: Carver BF (ed.) Wheat: Science and Trade. Wiley-Blackwell, Ames, IA.

Kosambi, D.D. 1944. The estimation of map distances from recombination values. Ann. Eugen. 12:172-175.

Martin, J.N., B.F. Carver, R.M. Hunger, and T.S. Cox. 2003. Contributions of leaf rust 
resistance and awns to agronomic and grain quality performance in winter wheat. Crop Sci. 43:1712-1717.

Pailloix, A., V. Ayme, and B. Moury. 2009. Durability of plant major resistance genes to pathogens depends on genetic background, experimental evidence and consequences for breeding strategies. New Phytol. 183:190-199.

Röder, M.S., V. Korzun, K. Wendehake, J. Plaschke, M. Tixier, P. Leroy, and M.W. Ganal. 1998. A microsatellite map of wheat. Genetics. 149:2007-2023

Roelfs, A.P., and J.W. Martens. 1988. An international system of nomenclature for Puccinia graminis f. sp. tritici. Phytopathology 78:526-533.

Rowland, G.G., and E.R. Kerber. 1974. Telocentric mapping in hexaploid wheat of genes for leaf rust resistance and other characters derived from Aegilops squarrosa. Can. J. Genet. Cytol. 16:137-144.

Singh, D., V. Mohler, and R. F. Park. 2012. Discovery, characterization and mapping of wheat leaf rust resistance gene Lr71. Euphytica. Doi 10.1007/s10681-012-0786-x

Singh, R.P., J. Huerta-Espino, R. Sharma, A.K. Joshi, and R. Trethowan. 2007. High yielding spring bread wheat germplasm for global irrigated and rainfed production systems. Euphytica 157:351-363.

Somers, D., P. Isaac, and K. Edwards. 2004. A high-density microsatellite consensus map for bread wheat (Triticum aestivum L.). Theor. Appl. Genet. 109:1105-1114.

Song, Q.J., J.R. Shi, S. Singh, E.W. Fickus, J.M. Costa, J. Lewis, B.S. Gill, R. Ward, and P.B. Cregan. 2005. Development and mapping of microsatellite (SSR) markers in wheat. Theor. Appl. Genet. 110:550-560.

Stakman, E.C., D.M. Stewart, and W.Q. Loegering. 1962. Identification of physiological 
races of Puccinia graminis var. tritici. US Department of Agricultural Publications E617. USDA, Washington, D.C.

Sun, X, G. Bai, B.F. Carver, and R. Bowden. 2009. Molecular markers for wheat leaf rust resistance gene Lr41. Mol. Breed. 23:311-321.

Sun, X., G. Bai, B.F. Carver, and R. Bowden. 2010. Molecular mapping of wheat leaf rust resistance gene Lr42. Crop Sci. 50:59-66.

Zhang, J.X., R.P. Singh, J.A. Kolmer, J. Huerta-Espino, Y. Jin, and J.A. Anderson. 2008. Genetics of leaf rust resistance in Brambling wheat. Plant Dis. 92:1111-1118. 
Table 1. Segregation of Lr42 in $F_{2}$ and $F_{2: 3}$ populations derived from a cross of 'KS93U50' $\mathrm{x}$ 'Morocco' when inoculated with Puccinia triticina Eriks. isolate PNMR at seedling stage

\begin{tabular}{cccccc}
\hline Generation & $\begin{array}{c}\text { No. of } \\
\text { Lines }\end{array}$ & Observed ratio $^{\dagger}$ & $\begin{array}{c}\text { Expected } \\
\text { ratio }^{\dagger}\end{array}$ & $X^{2}$ & $P$-value \\
F2 & 371 & $89: 282$ & $1: 3$ & 0.202 & 0.653 \\
F3 & 361 & $86: 167: 113$ & $1: 2: 1$ & 7.693 & 0.021 \\
\hline
\end{tabular}

$†$ F2 ratio is resistant:susceptible; F3 ratio is resistant:segregating:susceptible 
Table 2 Segregation of marker alleles located on chromosome 1D.

\begin{tabular}{lccccc}
\hline Marker & $\begin{array}{c}\text { No. of Lines } \\
\text { Xgdm33 }\end{array}$ & $\begin{array}{c}\text { Observed } \\
\text { ratio }^{\dagger}\end{array}$ & $\begin{array}{c}\text { Expected } \\
\text { ratio }^{\dagger}\end{array}$ & $X^{2}$ & $P$-value \\
Xwmc432 & 359 & $76: 174: 109$ & $1: 2: 1$ & 6.404 & 0.041 \\
Xcfd0015 & 364 & $84: 169: 111$ & $1: 2: 1$ & 5.863 & 0.053 \\
Xgwm337 & 355 & $80: 188: 87$ & $1: 2: 1$ & 1.518 & 0.468 \\
Xgdm60 & 359 & $89: 183: 87$ & $1: 2: 1$ & 0.159 & 0.924 \\
Xgwm458 & 357 & $93: 173: 91$ & $1: 2: 1$ & 0.361 & 0.835 \\
\hline
\end{tabular}

$\dagger$ Ratio is resistant:segregating:susceptible 
Figure Legend

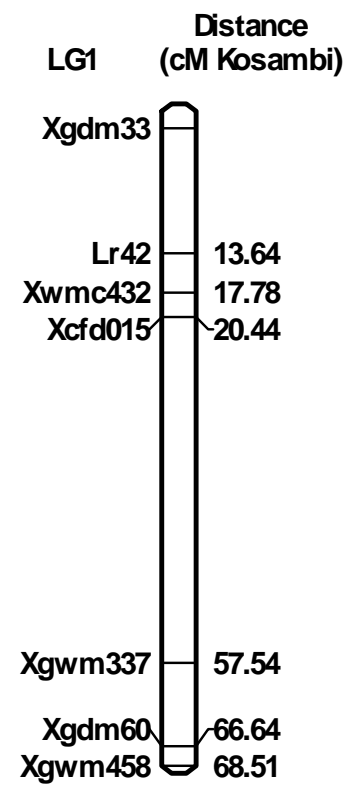

Figure 1. A genetic linkage map developed from the $\mathrm{F}_{2}$ population of 'KS93U50' $\mathrm{x}$ 'Morocco' showing Lr42 on the short arm of the chromosome 1D of wheat 